\title{
Utilization of Banana Peel Flour in Biscuit Making as Wheat Flour Substitute
}

\author{
Mozeda Khatun, Md. Wadud Ahmed, Md. Mosharraf Hossain, Poly Karmoker, and Abdullah Iqbal
}

\section{ABSTRACT}

The production of biscuits utilizing ripe banana peel flour (BPF) as a wheat flour (WF) alternative is presented in this study. Locally available Sabri banana peel was dried into a cabinet dryer at $65^{\circ} \mathrm{C}$ for 8 hours. The dried peel then turned into powder and sieved. The flours used in the preparation of the biscuits were analyzed for proximate composition. BPF contained a higher amount of fat compared to WF. Five samples of biscuits $S_{1}, S_{2}, S_{3}, S_{4}$, and $S_{5}$ substituting WF with $0,5,10,20$, and $30 \%$ BPF in the standard biscuits were prepared $S_{1}$ denoted the control sample adding no BPF. The proximate composition and sensory quality of the produced biscuits were tested. All of the biscuit samples had greater weights than the control biscuit. In comparison to the control biscuit, BPF enriched biscuits had reduced diameter. Biscuits made with $10 \%$ BPF had a greater spread ratio than those made with other ingredients. The moisture, protein, fat, and total sugar content of biscuit samples were found in the range of 4.05$5.32 \%, 6.60-9.00 \%, 10.00-10.32 \%$, and $17.00-25.00 \%$, respectively. A sharp decrease in protein content was observed with the increase of BPF in the biscuits. A slight increase of fat was observed in the BPF substituted biscuits. The ash content in the control sample was $1.5 \%$, and that in the banana peel substituted samples ranged from $1.80 \%$ to $2.0 \%$. BPF substitution showed a downward trend in terms of color, flavor, texture, and general acceptability. The panelists rated sample $S_{1}$ as having the highest overall acceptability. Among the BPF-containing biscuits, sample $\mathbf{S}_{\mathbf{2}}$ had the best overall acceptance, followed by samples $S_{3}, S_{4}$, and $S_{5}$. In terms of general acceptability, however, there are no notable variations between samples $S_{2}$ and $S_{3}$. According to sensory analysis, quality BPF biscuits may be prepared by replacing up to $10 \%$ of the WF with BPF.

Keywords: Banana peel flour, wheat flour substitute, biscuits, proximate composition, sensory assessment.

\section{INTRODUCTION}

Agricultural by-products are getting more attention from many researchers and food manufacturers by converting the by-product into food. By-products of vegetables and plants are normally discarded after harvesting or processing as it is not usually used in food production [1]. Several studies reported on the production of food products using byproducts and proved that it could improve the food's nutritional value and dietary fiber [2]-[5]. Many researchers are getting more interested in utilizing the usage of byproducts. Banana peel is an important by-product rich in different nutrients that have been used to produce enormous food products [2].

Most developing countries, such as Bangladesh, have unused banana peels, which account for about $40 \%$ of the entire weight of fresh bananas. [6], [7]. Turning the peel into $\mathrm{BPF}$ is one approach to using this valuable by-product. This product can be developed into new products with standardized compositions and functional qualities for a range of manufacturing and household applications. Banana peel extract has more antioxidants and phenolic components than banana pulp, indicating that the peels could be used in a
Submitted : November 02, 2021

Published : November 26, 2021

ISSN: 2684-1827

DOI: $10.24018 /$ ejfood.2021.3.6.407

Mozeda Khatun

Department of Food Technology,

Chapainawabganj Polytechnic Institute,

Bangladesh.

(e-mail: bilkis1202@gmail.com)

Md. Wadud Ahmed

Department of Agricultural Engineering,

Sher-e-Bangla Agricultural University,

Bangladesh.

(e-mail: wahmed@sau.edu.bd)

Md. Mosharraf Hossain

Inspector of Taxes, Circle-15, Zone-

Rajshahi, National Board of Revenue,

Bangladesh.

(e-mail: hossain030@gmail.com)

Poly Karmoker

Department of Food Technology and

Rural Industries, Bangladesh Agricultural

University, Bangladesh.

(e-mail: poly.ftri@gmail.com)

Abdullah Iqbal*

Department of Food Technology and

Rural Industries, Bangladesh Agricultural

University, Bangladesh.

(e-mail: iqbal21155@bau.edu.bd)

*Corresponding Author

broad range of foods and nutritional supplements. [2], [5], [8], [9]. Banana peel's chemical composition and amount of resistant starch (RS) influence its potential uses and functional properties [10], [11]. Banana peel nutrients can lower the risk of heart disease and may also help with weight management strategies [2], [12].

There has been a surge in consumer interest in vitamins, minerals, unsaturated fatty acids, bioactive substances, and fiber in food items in the recent decade due to the increased focus on functional food products and consumer health and wellness. The reuse of banana waste produced, including peel, might enhance raw material output and, as a result, alleviate the food industry's massive waste disposal problems. In many studies, WF has been substituted with flour from fruits waste or by-products to produce bakery items because of specific eating habits, new consumer behavior, economic reasons, and commercial necessities. However, bakery items from composite flour are not common in Bangladesh. Therefore, this study aims to evaluate the nutritional quality of WF and BPF composite biscuits determining proximate compositions and acceptability of Bangladeshi consumers. 


\section{MATERIALS AND MethodS}

\section{A. Raw Materials}

The study was carried out in the Department of Food Technology and Rural Industries, Bangladesh Agricultural University (BAU), Mymensingh. Locally purchased ripe Sabri bananas, WF (Teer brand), eggs, sugar, milk powder, baking powder, salt, and other ingredients were used in this study. Reagent-grade chemicals and food-grade polythenes were supplied from the laboratory stocks.

\section{B. Preparation of $B P F$}

Bananas were washed in clean water to remove adhering dirt, filth, and other undesirables. The bananas were then washed and peeled using a knife, with the skins cut into $1.0 \mathrm{~cm}$ thick slices. After that, the slices were steam blanched to destroy the existing enzymes. The blanched banana peels were dried on stainless steel trays in a cabinet dryer at $65{ }^{\circ} \mathrm{C}$ for 8 hours. After allowing the dry pieces to cool to room temperature, they were ground in a crushing mill and sieved to get fine flour. After that, the flour is stored in plastic bags for future use.

\section{Preparation of BPF Substituted Biscuits}

Table I illustrates the basic formulation for preparing BPF substituted biscuits. Five samples were made. Sample $S_{1}$ was a control in which no BPF was added. On the other hand, samples $\mathrm{S}_{2}, \mathrm{~S}_{3}, \mathrm{~S}_{4}$, and $\mathrm{S}_{5}$ contained $5 \%, 10 \%, 20 \%$, and $30 \% \mathrm{BPF}$, respectively. The pre-weighed sugar, salt, egg, and hydrogenated fat (Dalda) were mixed until the sugar dissolved. The required amount of WF and BPF, baking powder, and vanilla were added and combined well to produce appropriate dough. After letting the dough rest for a bit, it was rolled out to a uniform thickness of $3 \mathrm{~mm}$. With a $4 \mathrm{~cm}$ diameter cutter, the sheet was cut into the required form and size of biscuits, then cooked for 10 to 15 minutes at 180 to $210{ }^{\circ} \mathrm{C}$. It was then allowed to cool to room temperature before being packaged in plastic bags. The process was the same for all of the formulas.

TABLE I: THE BASIC FORMULATION OF BPF SUBSTITUTED BISCUITS

\begin{tabular}{cccccc}
\hline \multirow{2}{*}{ Ingredients } & \multicolumn{5}{c}{ Samples* } \\
\cline { 2 - 6 } & $\mathrm{S}_{1}$ (Control) & $\mathrm{S}_{2}$ & $\mathrm{~S}_{3}$ & $\mathrm{~S}_{4}$ & $\mathrm{~S}_{5}$ \\
\hline WF(g) & 100.00 & 95.00 & 90.00 & 80.00 & 70.00 \\
BPF (g) & - & 5.00 & 10.00 & 20.00 & 30.00 \\
Sugar (g) & 60.00 & 60.00 & 60.00 & 60.00 & 60.00 \\
Dalda (g) & 20.00 & 20.00 & 20.00 & 20.00 & 20.00 \\
Milk powder (g) & 5.00 & 5.00 & 5.00 & 5.00 & 5.00 \\
Bicarbonate (g) & 0.50 & 0.50 & 0.50 & 0.50 & 0.50 \\
Salt (g) & 1.00 & 1.00 & 1.00 & 1.00 & 1.00 \\
Egg (g) & 40.00 & 40.00 & 40.00 & 40.00 & 40.00 \\
Vanilla & 2 drops & 2 drops & 2 drops & 2 drops & 2 drops \\
\hline
\end{tabular}

*(WF was replaced with BPF at 5\%,10\%, 20\%, and 30\% substitution level by weight in samples $S_{2}, S_{3}, S_{4}$ and $S_{5}$. Sample $S_{1}$ was the control that contained no BPF).

\section{Determination of Proximate Composition}

Proximate composition of BPF, WF, and BPF substituted biscuits were determined using published methods of AOAC [13]. The amount of carbohydrate was obtained mathematically, i.e., deducting the determined protein, moisture, fat, and ash from 100. All parameters were measured in triplicate, and the mean value was taken for comparison.

\section{E. Determination of Spread Ratio}

The spread ratio is an important parameter to evaluate the baking quality of a product. The following equation measured the spread ratio of BPF substituted biscuits:

$$
\text { Spread ratio }=\frac{\text { Diameter }(D)}{\text { Thickness }(T)}
$$

Here, $\mathrm{D}$ is the mean diameter $(\mathrm{cm})$, and $\mathrm{T}$ is the mean thickness $(\mathrm{cm})$.

\section{F. Sensory Evaluation of Prepared Biscuits}

A sensory testing panel assessed the consumer perception of prepared biscuits, whereas a hedonic scale was used to obtain individual scores. The participants were selected at random. The panelists rated their acceptability of the product on a 1-9 point hedonic scale. Panelists scored the product's acceptability on a 1-9 point hedonic scale. The scale was constructed in such a way that score 9 indicates like extremely, whereas score 1 indicates dislike extremely.

\section{G. Statistical Analysis}

Data collected from the sensory evaluation were analyzed using Analysis of Variance (ANOVA) and the mean procedure of SAS (Statistical Analysis System). The mean differences were detected using Duncan's New Multiple Range Test (DMRT). Statistical analyses were done using STAR (Statistical Tools for Agricultural Research) and WASP2 statistical internet package software.

\section{RESULTS AND DISCUSSION}

\section{A. Proximate Composition of Banana Peel, BPF, and WF}

Banana peel, BPF, and WF were assessed for moisture, protein, crude fat, crude fibre, ash, and total carbohydrate content (Table II). Banana peel has a lower protein level $(4.77 \%)$ than BPF $(10.04 \%)$. However, WF had a slightly greater protein level $(11.02 \%)$ than BPF. On the other hand, BPF had a lower carbohydrate content $(54.01 \%)$ than WF (74\%). Similarly, ash content of BPF was higher than that of WF. The findings of this research agree with that of [9], who reported $7.25-10.04 \%$ protein, $4.81-10.04 \%$ fat, and $54.01-$ $60.81 \%$ carbohydrate in BPF. Reference [2] shows $1.1 \%$ protein, $1.7 \%$ fat, $0.79 \%$ ash, $11.8 \%$ carbohydrate in the matured green banana peel. Reference [14] analyzed the WF for moisture, protein, fat, ash, total carbohydrate contents, and the results were $13.83 \%, 11.66 \%, 1.36 \%, 1.13 \%$, and $85.85 \%$, respectively. The variations in these components might result from varietal variances, agro-ecological conditions, analytical methodologies, or time gaps between harvesting and evaluation. [2], [15].

TABLE II: COMPOSITION OF BANANA PEEL, BPF AND WF

\begin{tabular}{cccc}
\hline Components & Banana peel & $\begin{array}{c}\text { Banana peel } \\
\text { Flour (BPF) }\end{array}$ & $\begin{array}{c}\text { Wheat flour } \\
\text { (WF) }\end{array}$ \\
\hline Moisture (\%) & 81 & 11.2 & 12.4 \\
Protein (\%) & 4.77 & 10.04 & 11.02 \\
Fat (\%) & 1.7 & 5.97 & 0.95 \\
Ash (\%) & 0.70 & 18.87 & 0.8 \\
Total carbohydrate & 9.4 & 54.01 & 74 \\
Crude fiber & 11.95 & 11.09 & - \\
\hline
\end{tabular}




\section{B. The Effect of BPF on the Physical Properties of Biscuits}

Table III summarizes the physical features of biscuits. The weight of the BPF biscuit samples was greater than that of the control biscuits that did not contain BPF. The biscuit using $10 \% \mathrm{BPF}$ had the largest weight in comparison to the other samples. The diameter of the control biscuit was greater than the diameter of the biscuits containing BPF. The control biscuit had a greater thickness. Spread ratio is a critical quality characteristic for biscuits since it connects strongly with texture, particle fineness, bite, and complete sensation.

TABLE III: EFFECT OF BPF ON PHYSICAL PROPERTIES OF BISCUITS

\begin{tabular}{crrrrr}
\hline $\begin{array}{c}\text { Biscuit } \\
\text { type }\end{array}$ & $\begin{array}{c}\text { Weight } \\
(\mathrm{g})\end{array}$ & $\begin{array}{c}\text { Diameter, } \\
\mathrm{D}(\mathrm{cm})\end{array}$ & $\begin{array}{c}\text { Thickness, } \\
\mathrm{T}(\mathrm{cm})\end{array}$ & $\begin{array}{c}\text { Spread ratio } \\
(\mathrm{D} / \mathrm{T})\end{array}$ & $\begin{array}{c}\text { Moisture } \\
(\% \text { dry } \\
\text { basis })\end{array}$ \\
\hline $\mathrm{S}_{1}$ & 4.95 & $\mathbf{4 . 7 0}$ & $\mathbf{0 . 6 4}$ & $\mathbf{7 . 3 5}$ & $\mathbf{5 . 3 2}$ \\
$\mathrm{S}_{2}$ & 5.00 & 4.42 & 0.63 & 7.02 & 5.15 \\
$\mathrm{~S}_{3}$ & $\mathbf{5 . 0 5}$ & 4.43 & 0.62 & 7.15 & 5.00 \\
$\mathrm{~S}_{4}$ & 5.02 & 4.35 & 0.62 & 7.02 & 4.60 \\
$\mathrm{~S}_{5}$ & 4.96 & 4.30 & 0.61 & 7.03 & 4.50 \\
\hline
\end{tabular}

The inclusion of BPF has a noticeable effect on the spread ratio of biscuits. The spread ratio of biscuits containing $10 \%$ BPF was greater than the spread ratio of other samples containing BPF, ranging from 7.02 to 7.15. Study [16] found the spread ratio of the cassava biscuits in the range of 6.79 to 7.35. Reference [17] reported the spread ratio of cabbage biscuits in the range of 6.31 to 6.85 . Hence, the spread ratio of prepared biscuit samples under study agrees with those reported by other authors. The high spread ratio of prepared biscuits indicates less hydrophilic starch added from plant by-products. However, an increase in the biscuit spread ratio might indicate a lack of interaction between the protein and carbohydrate networks in the biscuits [10].

\section{Composition of BPF Substituted Biscuits}

Five distinct samples of biscuits $\mathrm{S}_{1}, \mathrm{~S}_{2}, \mathrm{~S}_{3}, \mathrm{~S}_{4}$, and $\mathrm{S}_{5}$ containing $0,5,10,20$, and $30 \%$ BPF were prepared, and their chemical parameters were determined to evaluate their quality. Table IV shows the chemical composition of the treatments.

TABLE IV: CHEMICAL COMPOSITION OF PREPARED BISCUITS

\begin{tabular}{cccccc}
\hline Parameters & \multicolumn{5}{c}{ Samples } \\
\cline { 2 - 6 }$(\%)$ & $\mathrm{S}_{1}$ & $\mathrm{~S}_{2}$ & $\mathrm{~S}_{3}$ & $\mathrm{~S}_{4}$ & $\mathrm{~S}_{5}$ \\
\hline Moisture & 5.32 & 5.15 & 5.00 & 4.60 & 4.50 \\
Protein & 9.00 & 7.10 & 6.95 & 6.65 & 6.60 \\
Fat & 10.56 & 10.65 & 10.68 & 10.79 & 10.80 \\
Ash & 1.50 & 1.80 & 1.90 & 1.95 & 2.00 \\
Total sugar & 17.00 & 19.00 & 22.50 & 24.00 & 25.60 \\
Total carbohydrate & 74.18 & 75.85 & 76.00 & 76.50 & 76.58 \\
\hline
\end{tabular}

The amount of moisture of all treatments was in the range of $4.05 \%$ to $5.32 \%$. Some variations in moisture contents in biscuits might be due to the difference in initial moisture contents in BPF biscuits for baking and subsequent storage conditions and packaging materials. Additionally, as seen in Table IV the moisture level of control biscuits $S_{1}$ was greater than that of BPF biscuits. This might be because BPF contains more solid content than WF. Study [16] found moisture content in cassava flour biscuits in the range of 4.5 to 5.32. Reference [7] reported moisture content in banana and banana peel-rich cookies in the range of $2.28-3.35 \%$.
The moisture contents in biscuit samples under this study are slightly lower than that of other published studies [18], [19].

The ash level of prepared biscuit samples varied between 1.5 and $2 \%$. The highest ash concentration was observed in sample $S_{5}$, while the lowest was found in sample $S_{1}$. Higher BPF addition increased the ash content of several samples as the BPF contains a greater proportion of ash than WF. According to [17], the ash level of cabbage flour biscuits ranges between 1.06 and $1.19 \%$. A wide range of ash contents has been recorded for bread goods containing banana peel powder. [20].

Different biscuit samples $\mathrm{S}_{1}, \mathrm{~S}_{2}, \mathrm{~S}_{3}, \mathrm{~S}_{4}$, and $\mathrm{S}_{5}$ contained protein $9.0 \%, 7.10 \%, 6.95 \%, 6.65 \%$, and $6.60 \%$, respectively, indicating that protein content decreases with the increase in BPF in prepared biscuits. So, it may be concluded that low protein BPF substituted biscuits may be processed with the addition of flour at different levels. The fat content of 5 different formulated biscuits samples $S_{1}, S_{2}$, $\mathrm{S}_{3}, \mathrm{~S}_{4}$, and $\mathrm{S}_{5}$ with different levels of BPF contained 10 , $10.1,10.15,10.30$, and $10.32 \%$, respectively, which indicates that fat content increase with the increase of $\%$ BPF. The fat content of the BPF biscuit and control biscuit was slightly different. The maximum fat content $(10.32 \%)$ was found in sample $\mathrm{S}_{5}$, where WF was replaced with $30 \%$ $\mathrm{BPF}$, while the lowest fat content $(10.00 \%)$ was found in sample $S_{1}$. Sugar content varied from 17.0 to $27.0 \%$ within treatments. Total carbohydrate content was $74.18 \%$, $75.85 \%, 76.00 \%, 76.50 \%$, and $76.58 \%$ in samples $S_{1}, S_{2}, S_{3}$, $\mathrm{S}_{4}$, and $\mathrm{S}_{5}$. The total carbohydrate content of biscuits made with BPF was greater than biscuits made without BPF.

\section{Sensory Evaluation}

Twenty semi-trained panellists examined the biscuits that had been produced. The mean ratings for the biscuits' color, taste, texture, and general acceptability are mostly different The analysis of variance revealed that all of these sensory features were significantly $(\mathrm{P}<0.05)$ different amongst the biscuit samples, indicating that the sensory attributes of the biscuit samples demonstrated variable degrees of acceptance (Table V).

TABLE V: MEAN SCORE FOR FlaVOR, COLOR, TEXTURE AND OVERALL

\begin{tabular}{ccccc}
\multicolumn{5}{c}{ ACCEPTABILITY OF FORMULATED BISCUITS } \\
\hline $\begin{array}{c}\text { Sample } \\
\text { code }\end{array}$ & Color & Flavor & Texture & $\begin{array}{c}\text { Overall } \\
\text { Acceptability }\end{array}$ \\
\hline $\mathrm{S}_{1}$ & $7.47^{\mathrm{a}}$ & $7.94^{\mathrm{a}}$ & $7.47^{\mathrm{a}}$ & $7.20^{\mathrm{a}}$ \\
$\mathrm{S}_{2}$ & $6.07^{\mathrm{b}}$ & $6.94^{\mathrm{b}}$ & $7.47^{\mathrm{a}}$ & $6.54^{\mathrm{b}}$ \\
$\mathrm{S}_{3}$ & $5.80^{\mathrm{b}}$ & $6.94^{\mathrm{b}}$ & $7.47^{\mathrm{a}}$ & $6.50^{\mathrm{b}}$ \\
$\mathrm{S}_{4}$ & $5.74^{\mathrm{b}}$ & $6.87^{\mathrm{b}}$ & $7.47^{\mathrm{a}}$ & $5.90^{\mathrm{b}}$ \\
$\mathrm{S}_{5}$ & $5.94^{\mathrm{b}}$ & $6.74^{\mathrm{a}}$ & $7.47^{\mathrm{a}}$ & $5.87^{\mathrm{b}}$ \\
LSD & 0.4825 & 0.5067 & 0.6345 & 0.5376 \\
\hline
\end{tabular}

Means with the same superscript within a column are not significantly different $(\mathrm{p}<0.05)$.

The control biscuit had the highest score (7.47) and considerably varied from the other biscuits incorporating BPF. The remaining four BPF added samples were similarly acceptable in terms of colour, whereas colour scores of biscuits were followed the trend as $S_{1}>S_{2}>S_{3}>S_{4}>S_{5}$, with a range of 5.94 to 7.47. In the DMRT test, the highest score was for the taste of the control biscuit $\left(\mathrm{S}_{1}\right)$, which was substantially different from the biscuit containing 5\% BPF $\left(\mathrm{S}_{2}\right)$. While the taste of biscuits containing 5 to $20 \% \mathrm{BPF}$ 
was acceptable, biscuits using 30\% $\mathrm{BPF}\left(\mathrm{S}_{5}\right)$ received the lowest grade. The control biscuit $\left(\mathrm{S}_{1}\right)$ texture was more favoured (7.07) than those with BPF biscuits. The texture score of biscuits followed the trend as $\mathrm{S}_{1}>\mathrm{S}_{2}>\mathrm{S}_{3}$. However, biscuits made with $20 \% \mathrm{BPF}\left(\mathrm{S}_{4}\right)$ and $10 \% \mathrm{BPF}$ $\left(\mathrm{S}_{3}\right)$ received the same score (5.80), and no significant difference was identified between samples made with BPF. The biscuit made with $30 \%$ BPF $\left(\mathrm{S}_{5}\right)$ had the lowest score (5.47); in other words, as the proportion of BPF substituted grew, the score for texture preferences fell. There were statistically significant variations in overall acceptability $(\mathrm{P}<0.05)$ across the samples. The control sample received the highest rating (7.2) and was statistically different from the other biscuits. However, biscuits were ranked in order of overall acceptability as follows $S_{1}>S_{2}>S_{3}>S_{4}>S_{5}$. Sample $S_{2}$ and $S_{3}$ have been accepted equally, and no significant difference consists between the two samples. Hence, it can be concluded that $10 \%$ BPF may be substituted with $90 \% \mathrm{WF}$ to prepare BPF supplemented biscuits. However, further study is needed to observe the rheological properties or behaviour of BPF supplemented biscuits.

\section{CONCLUSION}

BPF was prepared from blanched, dried peel slices using a crushing machine and sieved to utilize the powder as WF replacer in biscuit. BPF contained a lower amount of protein compared to WF. The biscuit samples moisture, protein, fat, and total sugar contents were found in the range of 4.05$5.32 \%, 6.60-9.00 \%, 10.0-10.32 \%$, and $17.00-25.00 \%$, respectively. It was observed that a sharp decrease in protein content occurred with the increase of BPF in the biscuits, whereas a slight decrease in fat content was observed. The BPF fortified biscuits contained a higher amount of ash than the control, indicating that the mineral content was increased due to the addition of BPF. Upon examination of the composition and sensory assessment of the prepared biscuits, it is observed that high-quality BPF enriched biscuits may be manufactured by replacing WF up to $10 \%$. The formulation may be enhanced with the addition of food colors, tastes, and other additives. As it is new thinking in the food sector, further research and study are needed before industrial trial.

\section{REFERENCES}

[1] T. B. N. Brito, M. S. L. Ferreira, and A. E. C. Fai. Utilization of Agricultural By-products: Bioactive Properties and Technological Applications. Food Rev. Int., vol. 00, no. 00, pp. 1-25, 2020.

[2] D. Mohapatra, S. Mishra, and N. Sutar. Banana and its by-product utilisation: An overview. J. Sci. Ind. Res. (India), vol. 69, no. 5, pp. 323-329, 2010.

[3] R. Chakraborty, S. Sabruna, R. Roy, S. Majumdar, and S. Roy. Banana pseudostem substitution in wheat flour biscuits enriches the nutritional and antioxidative properties with considerable acceptability. SN Appl. Sci., vol. 3, no. 1, pp. 1-12, 2021.

[4] N. Cordeiro, M. N. Belgacem, I. C. Torres, and J. C. V. P. Moura. Chemical composition and pulping of banana pseudo-stems. Ind. Crops Prod., vol. 19, no. 2, pp. 147-154, 2004.

[5] A. Amini Khoozani, J. Birch, and A. E. D. A. Bekhit. Production, application and health effects of banana pulp and peel flour in the food industry. J. Food Sci. Technol., vol. 56, no. 2, pp. 548-559, 2019.

[6] M. W. Woo, W. R. W. Daud, S. M. Tasirin, and M. Z. M. Talib. Optimization of the spray drying operating parameters - A quick trial- and-error method. Dry. Technol., vol. 25, no. 10, pp. 1741-1747, 2007.

[7] J. Alam. Development of Fiber and Mineral Enriched Cookies by Utilization of Banana and Banana Peel Flour. J. Microbiol. Biotechnol. Food Sci., vol. 10, no. 3, pp. 329-334, 2020.

[8] P. Wachirasiri, S. Julakarangka, and S. Wanlapa. The effects of banana peel preparations on the properties of banana peel dietary fibre concentrate. Songklanakarin J. Sci. Technol., vol. 31, no. 6, pp. 605$611,2009$.

[9] S. bin Ramli, A. F. M. Alkarkhi, Y. S. Yong, and A. M. Easa. Physicochemical Properties of Banana Flour as Influenced by Variety and Stage of Ripeness: Multivariate Statistical Analysis Article. $J$. Agric. Sci. Technol., vol. 4, no. 1, pp. 69-78, 2010.

[10] L. M. Mahloko, H. Silungwe, M. E. Mashau, and T. E. Kgatla. Bioactive compounds, antioxidant activity and physical characteristics of wheat-prickly pear and banana biscuits. Heliyon, vol. 5, no. 10, p. e02479, 2019.

[11] O. A. Olaoye, J. I. Ekeh, C. J. Okakpu, A. C. Uka, A. State, and A. State. Consumer Acceptability and Quality Characteristics of Cookies Produced from Composite Flours of Wheat and Banana/Avocado Peels. Ann. Food Sci. Technol., vol. 20, no. 1, pp. 56-64, 2019.

[12] H. T. Vu, C. J. Scarlett, and Q. V. Vuong. Phenolic compounds within banana peel and their potential uses: A review. J. Funct. Foods, vol. 40, no. November 2017, pp. 238-248, 2018.

[13] AOAC. Association of Official Analytical Chemist. 2012.

[14] M. W. Ahmed and M. N. Islam. Moisture Sorption Characteristics of Selected Commercial Flours (Wheat, Rice and Corn) of Bangladesh. Am. J. Food Sci. Technol., vol. 6, no. 6, pp. 274-279, 2018.

[15] M. Rahman, M. Ahmed, and M. Islam. Drying kinetics and sorption behavior of two varieties banana (sagor and sabri) of Bangladesh. SAARC J. Agric., vol. 16, no. 2, pp. 181-193, 2019.

[16] M. Sobhan. Study on the quality of biscuits prepared from wheat flour and cassava flour. Bangladesh Agricultural University, 2013.

[17] J. Nahar. Effect of cabbage powder on quality of biscuit. Bangladesh Agricultural University, 2013.

[18] R. Prajapati, S. Chandra, and Samsher. Study of the effect of composition of various food flours on the quality of developed biscuits. South Asian J. Food Technol. Environ., vol. 05, no. 01, pp. 771-777, 2019.

[19] B. D. Igbabul, B. M. Iorliam, and E. N. Umana. Physicochemical and Sensory Properties of Cookies Produced from Composite Flours of Wheat, Cocoyam and African Yam Beans. J. Food Res., vol. 4, no. 2, p. $150,2015$.

[20] E. Juarez-Garcia, E. Agama-Acevedo, S. G. Sáyago-Ayerdi, S. L. Rodríguez-Ambriz, and L. A. Bello-Pérez. Composition, digestibility and application in breadmaking of banana flour. Plant Foods Hum. Nutr., vol. 61, no. 3, pp. 131-137, 2006. 